\title{
The Pandemic Appears to Be Waning: What's Next for Our Universities
}

\author{
Joseph E. Steinmetz, PhD \\ Executive Director, Psychological Clinical Science Accreditation System \\ Former Chancellor, University of Arkansas
}

I have spent my career in higher education, including my student years, time as a faculty member conducting research and teaching in my field of behavioral neuroscience, and 26 years as an administrator. Those 26 years consisted of service as chair of the Department of Psychology at Indiana University (1995-2004), an associate dean at IU (2004-2006), dean of the College of Liberal Arts and Sciences at the University of Kansas (2006-2009), executive dean of Arts and Sciences and then executive vice president and provost at Ohio State University (2009-2015), and most recently chancellor of the University of Arkansas (2016-2021). During my time as an administrator, I saw my share of good and bad times in higher education. I think the good times far outweighed the bad times. Indeed, the resilience of our universities through rather significant changes in higher education-such as the development of new technologies, economic recessions, fluctuations in federal support for research, rapidly growing enrollments and several other major influences - has been impressive, especially in light of how slow our institutions can be in adapting to change. Nonetheless, our universities continue to make contributions to society through our missions of research and discovery, teaching and learning, and outreach and engagement. Then came the pandemic that hit the world in February of 2020.

In this paper, I will provide my insights into what I believe are the effects of the pandemic on our universities. I will briefly describe the state of higher education at the time the pandemic struck, summarize the challenges universities faced during the pandemic, make some predictions on what the post-pandemic environment will look like, then close with some reasons why I believe we should be optimistic about the future of higher education.

For full disclosure, I resigned as chancellor of the University of Arkansas in June of 2021, after serving five and onehalf years in the position. While there are always several factors that go into a difficult decision like this one, there were a few things that significantly impacted my thinking when I resigned (https://www. chronicle.com/article/whispers-to-rumors-to-resignation-u-of-arkansas-chancellor-resigns). Like many university ad- ministrators, the pandemic frankly wore me out. I can cite a variety of reasons for why this was the case. Universities should be a place where ideas are welcomed and debate about those ideas civil. It's this environment that I valued and enjoyed in my various leadership positions; this is what makes universities special. Sadly, I don't think this is the case anymore.

As the national political climate has polarized, so have discussions on campuses, and this has made the campus CEO position extremely difficult. And Arkansas is a very "red" state, where views of conservative legislators and members of the university community are often very different and therefore often clash. Particularly during the first six months of 2021, I often felt trapped between these polarizing sides, knowing that whatever decision I made, I would anger one side or the other. I received more "demand" letters and formal resolutions over the time of 
the pandemic than probably the prior 25 years I served as an administrator. People no longer approached issues from a "let's talk about this" manner but now a rather hardened "we demand" position. For the last several months I served as chancellor I often dreaded coming into the office because I knew there was likely another issue that I would have to deal with - this is crisis management, not strategic leadership, which I enjoyed.

Lastly, and possibly most importantly, I lost passion for the job, passion that has driven me over the 26 years I have been an administrator. At many of the commencement ceremonies I presided over as chancellor I told the graduates to find a career and calling that they were passionate about and not to settle for anything less. It was clear that I had lost my passion for the work I was doing - it was time for me to heed my own advice. So, I decided to step down as chancellor, a decision I thought best for me and for the institution.

The Pre-Pandemic State of Higher Education

Over the last few decades, arguably one of the most impactful events to affect higher education was the Great Recession caused by the burst of the U.S. housing market and a global financial crisis that lasted from 2007 to 2009. For public universities, the Great Recession led to significant reductions in states' support of higher education, as well as financial difficulties for many families. While there have been steady increases in state support over the last seven to eight years, adjusted for inflation, public universities are still receiving less than they did before the Great Recession (https://www. cbpp.org/research/state-budget-and-tax/ state-higher-education-funding-cutshave-pushed-costs-to-students). However, it seems that most public universities adjusted and recovered from the recession relatively quickly, in part by maintaining enrollments and raising tuition to backfill the losses of state support. For example, at four-year public universities tuition increased 37\% between 2008 and 2018 (https://www.cnbc.com/2019/10/24/ college-costs-have-increased-in-all-50states-over-the-past-10-years.html). While most universities agree that research funding is inadequate, overall research funding increased since the Great Recession. For example, the National Institutes of Health appropriation increased from $\$ 31.2$ billion to $\$ 41.7$ billion between 2010 and 2020 while the National Science Foundation appropriation increased from $\$ 6.9$ billion to $\$ 8.3$ billion during that same period (https://www. aaas.org/programs/r-d-budget-and-policy/historical-trends-federal-rd). All in all, I believe our universities were generally in good shape prior to the pandemic. With that said, there are at least four major areas of concern that universities were facing before the onset of the pandemic.

1. A Financial Model That Is Not Sustainable. For many years, public universities used the same model to support their operations, a combination of state support and student tuition and fees. This model is no longer sustainable. States have steadily reduced their funding for higher education over the last 20 years. The University of Arkansas serves as an example. In 2000, about $70 \%$ of the $\mathrm{U}$ of A budget was supported by dollars appropriated by the state and roughly $30 \%$ by tuition, fees, and other small sources of revenue. By 2018, that ratio more than flipped with less than $18 \%$ of the budget coming from state appropriations and about $72 \%$ coming from tuition, fees, private dollars, and other sources of support. While there are many reasons most states have reduced their support for higher education, I believe a major reason is that public education is no longer considered a public good, but rather a private good that benefits individuals more than society in general. In essence, the lost state dollars have been 
made up by increasing tuition and fees to the point where many families cannot afford to send students to college. Indeed, college cost increases have outstripped small gains in household incomes, and student debt has increased significantly. This trend cannot continue so universities must create a new financial model to survive. Other sources of revenue must be found, such as partnerships with the private sector, and universities must become more operationally efficient. Also, new ways to support research will have to be part of the model because all universities subsidize their research operations from general funds that include state dollars and student tuition.

2. Changing Student Demographics. For many years, major research universities have drawn students from mainly the white middle and upper middle classes and less from poorer, more diverse areas of our country. Population experts, however, predict a change in student demographics that could impact our public universities in what many are calling an "enrollment crisis" (https://www. cupahr.org/issue/feature/higher-ed-enrollment-cliff). This trend was evident before the pandemic began. Of note is the fact that the national birthrate has been declining since 2008, meaning fewer high school graduates will be available moving forward; this is particularly evident in the North and East (less so in the South and West). And most of the decline has been in the white population. Some are predicting that by the mid-2040s, we will be a "majority, minority country." These trends mean that for public universities, the traditional students who have been recruited are declining. This could significantly impact enrollments at many universities. It is interesting to note that increases in enrollment for major research universities, especially in the South and West, are predicted. I believe it would serve our research universities well if they took steps to increase admis- sion, retention, and graduation rates of students they have not traditionally enrolled.

3. Four Years of the Trump Administration. Donald Trump was elected president in 2016 before the pandemic began, and his administration and policies certainly affected higher education, mostly, in my opinion, in negative ways. Let me cite just a few examples.

First, the Trump administration was anti-immigration for the most part and this affected the recruitment and status of international students. It became harder for international students to enter (and stay) in the country, so universities saw a decline in the number of international students matriculating in the U.S. This had three very immediate effects: Revenue generated by tuition paid by these students fell. Other countries such as England, Canada, and Australia became more successful at recruiting these students, and this is likely to cause long-term effects on the relative competitiveness of U.S. universities in attracting students. And, perhaps most importantly, there has been a loss of valuable talent entering the U.S., talent that is particularly valuable for our research enterprise, as well as private sector employment.

Second, there was a major shift in how Title IX cases were viewed and handled as the regulations around Title IX shifted. Under the Obama administration, great care was taken to protect the complainant before, during, and after Title IX proceedings. Under the Trump administration, new regulations were written, including changes in the hearing process and a general shift of focus onto the rights of respondents. These changes resulted in the need for universities to increase the number of staff members working in the Title IX area. In addition, an increase in the number of suits and legal cases by respondents against the universities has 
been seen. I believe that universities successfully adjusted to the changes, however, and that the process continues to be fair to both parties involved. It is likely, though, that the process will change again as the Biden administration issues its directives.

Third, for the last several years the general respect and sense of importance of higher education by the public has been diminishing and this accelerated during the Trump administration, in part due to the negative attitude the administration had on higher education (e.g., Trump's threats concerning the University of California, Berkeley around issues of free speech). Many in this country are now questioning whether a college education is worth it. This is due, in part, to the accelerating cost of a college education (which is our fault). But there is a political angle, as well. Colleges and universities are generally considered by the political right to be very liberal places (which, for the most part, they are) that negatively influence the thinking of students (which there is no evidence for). This position has influenced the views of the general population. For example, even though it has been well established that college education increases earning potential, overall satisfaction with life, voting rates, and several other variables, a Gallup poll conducted in 2019 revealed that only 51\% of respondents rated a college education as very important, which is an all-time low. Importantly, the biggest shift in responses was in young adults (18-29 years old); eight years ago, $74 \%$ rated college as very important, whereas last year that number dropped to $41 \%$. Attitude toward the importance of college does depend on your party affiliation. Some recent data from Pew showed that $67 \%$ of Democrats had a favorable view of higher education, with $18 \%$ holding a negative view (https://www.pewresearch.org/social-trends/2019/08/19/the-growing-partisan-divide-in-views-of-higher-edu- cation-2). For Republicans, 33\% had a favorable view while $59 \%$ held a negative view. Reflecting the attitude of the political right on colleges and universities, mistrust of the "liberal agenda" seems to drive the negative attitude. These numbers should be of concern to higher education.

Fourth, during the Trump administration there was a general empowerment of some factions in society that were hidden and, for the most part, silent over the last several years. The increase in hate crimes, racism, and what I think of as a general "anti-intellectualism" grew over the last four years. This became evident to me the day after Donald Trump was elected: I received reports of many racist remarks being openly directed toward international students and students of color at the University of Arkansas the day after the election. While the campus was never truly free of these remarks, the incidents increased significantly to the point of making many of our students feel unsafe and unwelcome. Regarding the anti-intellectual climate in this country that has developed in recent times, one only needs to look at our response to the pandemic and this country's general lack of trust in science to deal with the worst health crisis we have seen in a century. Many chose to follow the advice of social media "experts" and politicians rather than scientists and public health experts, and this attitude continued even after effective and safe vaccines became available. The Trump administration did very little to engender trust in these experts, and I believe this fed the "anti-intellectual" movement that started years before.

4. Equity Issues in Higher Education. Even before the pandemic there existed an issue of equity around access and affordability of a college education. Simply put, higher education has generally favored white students from certain geographical areas that have access to good 
schools, college test preparation services, and the resources to attend college. The system has disadvantaged students of color, as well as first-generation and poor students, who have neither the access to $\mathrm{K}-12$ education equivalent to their affluent peers nor the financial means to attend college. Our major research universities have tended to admit elite students with high ACT or SAT scores, a solid K-12 education, and the financial means to pay the higher tuition generally charged. Poorer students have tended to go to regional colleges and universities (if they go at all). Don't get me wrong, these regional universities can and do provide excellent education (I am, in fact, a product of this education - thank you, Central Michigan University). But there is a large difference in how much is spent per student in these two kinds of public universities, as well as a large difference in outcomes (i.e., retention and graduation rates). Given the general shift in demographics discussed above, this equity issue needs to be addressed.

Issues Universities Faced During the Pandemic

Higher education, like all aspects of our society, was not prepared for the global pandemic that took hold in March of 2020. It hit harder and has lasted longer than most predicted and caused unprecedented issues for our universities, leading to a major disruption of our basic missions of teaching and learning, research and discovery, and outreach and engagement. For me, the seriousness of the pandemic became apparent while I was attending the Southeastern Conference President's and Chancellor's meeting and men's basketball tournament in Nashville, Tennessee. Within the span of 24 hours, the meeting was suspended, the tournament halted, and I enacted a series of decisions on how to deal with the pandemic on the University of Arkansas campus. The first of those was to essentially shut the campus down, pivoting to a $100 \%$ remote learning environment for our students and a work-from-home situation for our faculty and staff. I, like many others, did not think we would be dealing with the pandemic through the summer of 2021 (when I wrote this piece). Summarized here are some of the major issues that our universities faced during the pandemic.

1. Universities Took a Financial Hit. While only a few universities reduced tuition during the pandemic, many decreased fees, and there was a significant loss in revenue in auxiliary operations such as housing, dining, and athletics. At the University of Arkansas, we did not furlough faculty or staff or reduce hours, so personnel costs continued even though significant revenue was lost. We were also fortunate that we did not see an enrollment drop during the fall of 2020 even though we continued to deliver our courses mostly remotely. This was not the case nationally as student numbers fell during the 2020-21 academic year. There was also concomitantly an increase in expenses. These expenses include equipment and supplies to deal with keeping the campus safe during the pandemic (e.g., personal protective equipment, extra campus cleaning, Plexiglas barriers, masks, and vaccine-related costs), as well as a significant investment in technology to enable us to deliver courses remotely and in person when possible. The three federal subsidies to universities helped reduce this financial hit, but in the end the loss of revenue and addition of expenses were still greater than the federal assistance for most universities. I should also mention that a loss of jobs during the pandemic had a significant impact on the financial situation of our students and their families.

2. Popularity and Quality of Remote Courses. I was amazed at how adaptable our faculty was in shifting from a traditional face-to-face mode of instruction to a $100 \%$ remote environment; they 
stepped up and did well. However, some of the faculty struggled, some courses were not suited for remote delivery (e.g., art, architecture, music), and some of our students struggled to adapt to this format. In fact, one thing we learned during the pandemic is that overall, our students didn't like taking their courses remotely; they came to the university for the classroom experience and not to sit in their rooms in a remote class. There were many calls for tuition rebates across the country, which indicates that our students don't see remote delivery as equal value to traditional courses. And many faculty members are concerned that there may be knowledge gaps going forward, as it's hard to assess whether the remote experience created the same learning experience as traditional course delivery - I doubt it did.

3. Staff and Faculty Pivoted to Working at Home. While work-fromhome opportunities have been around for business and industry for the last several years, they have largely not been available in higher education. Except for a few essential workers, for the duration of the pandemic our faculty and staff worked from home for over a year, only returning in larger numbers in June of 2021. This arrangement did keep the campus safe during the pandemic. There is a difference in opinion between supervisors and those staff and faculty working from home on the overall quality and quantity of the work. Our faculty and staff believe they were as effective at home as on campus (and many want to continue this arrangement indefinitely). Some supervisors disagree and believe there was a slight drop-off in productivity of people working from home. This may, in part, be due to the type of work. Some jobs can be done effectively while remote, such as some financial and HR related jobs. Other jobs require faceto-face contact with the students and others on campus; these positions are not candidates for continuation of remote working arrangements.

4. Polarized Views of Students, Parents, Faculty and Staff on the Seriousness of the Pandemic. A major reason the pandemic has lasted for as long as it has is that a polarized view on the seriousness of the COVID-19 virus has existed since the pandemic began. This was evident in the communications I received from students, parents, faculty and staff throughout the pandemic. From the day we made the decision to go $100 \%$ remote for teaching and research in March of 2020 until the day I stepped down as chancellor, it was common for me to receive contrasting e-mails within the same hour. I received angry emails from students and parents challenging my decision to go remote for classes and mandating masks and physical distancing for those classes and functions being held on campus - it was common to hear from this group that the virus was a hoax or that it only affected old and sick people. On the other hand, I received many emails from nervous faculty and staff blasting me for not keeping the campus safe enough. This group wanted no inperson classes, as well as mask mandates, vaccine mandates, and maintenance of physical distancing for all situations even after the vaccine became widely available. In other words, this group would shut everything down and keep it shut down until the virus disappeared. I rarely heard from people who thought what we were doing was a good course of action.

5. The Emergence of a Severely Polarized Political Environment. I cannot think of another time in my lifetime when there has been more political polarization than currently, and this has affected our universities, especially during the pandemic. It doesn't matter the issue-the pandemic, immigration, Title IX, social justice-our country is deeply divided. This means that our universities had to deal with this 
polarized environment in setting policy, curriculum, research and more. In some states, like Arkansas, one political party holds a super-majority so there is little if any compromise on any issue. This puts universities in very difficult positions as they try to balance the views and needs of students, faculty, staff, and alumni who hold many different perspectives.

6. State Governance. Even though support for higher education has decreased in virtually every state, state legislators and governors have not reduced their desire to exercise control and oversight of universities. In fact, I believe that this oversight has increased over the last several of years. With this climate as a backdrop during the pandemic, particularly in deeply "red" states like Arkansas, new laws and statutes were passed that have had a significant impact on public universities. And this impact is largely negative. In Arkansas for example, new state laws were passed that targeted transgender people and how they can participate in sports. Two laws were passed that made it more difficult for the university to deal with the pandemic; one law forbid mask mandates while the second law forbid vaccine mandates. Both laws limited how the university could deal with the pandemic. New freedom of speech laws were established during the pandemic that were largely unnecessary.

And a bill preventing universities from removing or moving statues, building names and monuments was adopted. This bill was triggered, in part, by a discussion on the University of Arkansas campus concerning the legacy of William J. Fulbright, a former student, U of A president, and U.S. Senator. While Senator Fulbright certainly had a significant, positive impact on the country through his opposition to the Vietnam War and establishment of the Fulbright Foreign Exchange program, he was also a segregationist who signed the "Southern Manifesto" and failed to vote in favor of the civil rights bill (see Woods, 1995, for a comprehensive review of the Fulbright legacy). This mixed legacy created a split on campus with many suggesting a statue located in a prominent place on campus be removed along with his name from the College of Arts and Sciences. State legislators were incensed with the idea that the statue would be moved or removed. The legislation made neither of these options doable, even though I recommended that the statue be moved to a location on campus where the Senator's life could be historically contextualized. It was difficult enough to manage the university during the pandemic. Legislation such as cited above made it even more difficult. And this situation was not unique to Arkansas.

7. Deepening Equity Issues. We entered the pandemic with inequities in access and affordability to higher education as a serious issue. The pandemic magnified this issue. Students struggling to pay for their college experience were hit hard as many had to work two and even three jobs to remain in school; these jobs disappeared during the pandemic, making paying for college even more difficult. Inequity of accessing good healthcare was another issue exposed during the pandemic, as was access to technology. As our students went home, we discovered that many didn't have good internet access, making remote course work difficult or impossible. It was clear that many of our students of color were affected worse than our white students, thus deepening the existing equity issues.

8. Faculty Were Impacted. During the pandemic I had many discussions with other chancellors and presidents on how the virus was affecting their campuses. All reported that their faculty were concerned about how the university was handling the pandemic and expressed feelings of fear and anxiety about returning to campus even when the vaccine was widely available. Faculty senates 
across the country forwarded numerous petitions on a variety of topics, including mask mandates, vaccine mandates, COVID-19 testing mandates, reinstatement of in-person classes, compensation increases for the pivot to remote learning, and suggestions that remote teaching be a permanent option for faculty. Further, many of us campus leaders seemed to get an increase in communications indicating we were not doing enough to battle the pandemic or social justice issues or to respond to state legislators who were passing laws that negatively impacted the university. The pandemic did impact the faculty significantly, especially our more junior colleagues. For example, many institutions stopped or delayed the tenure clock in recognition of the negative impact of the pandemic on research and teaching; many untenured faculty are very nervous about their upcoming reviews.

9. Research Was Impacted. Research ground to a halt as physical distancing and remote work requirements kept researchers home and not on campus. Libraries were closed. Graduate students working on research projects saw their scholarship stopped. Research funds were not used, presenting problems for maintaining infrastructure and other issues. It will be several years before we completely understand the impact the pandemic had on our university research enterprise in this country.

10. Crisis Management Mode. Arguably the biggest impact of the pandemic on me was that I felt I was nothing more than a crisis manager for the university instead of thinking about strategic planning and the long-term vision for the university. I seemed to be in a mode of dealing with the crisis of the day. Many things in the planning stage were placed on hold for financial or time-constraint reasons. This was not good for the long-term health of the institution.

\section{Post-Pandemic Issues}

At the time of writing (September
2021), the pandemic is again surging across the country, and it is clear that universities will go through another academic year dealing with COVID-19 and its variants. When we eventually emerge from the pandemic, there are many issues that our universities will face. Some of these existed before the pandemic, some were worsened by the pandemic, and some were created by the pandemic. I present some examples here.

1. Development of a New Financial Model. As I indicated, the current financial model on which public universities operate is not sustainable. This issue still needs to be addressed and must now include a post-pandemic financial recovery period that deals with pandemic-related revenue losses and expenses and places universities on a stable financial footing moving forward. This new financial model must also reflect the changing student demographics.

2. Unsolved Social Justice Issues. While the George Floyd murder exposed equity and inclusion issues in this country and universities took steps to deal with these issues, as a society we are a long way from true equity for all in this country, including in our universities. I don't believe these issues will fade to the background as they have in the past, but rather remain front and center until solved. Our universities should be on the front line in these efforts.

3. Athletics. Just as our financial mod$\mathrm{el}$ is not sustainable, neither is our current model of college athletics. Budgets for athletics departments have gotten out of control, driven mainly by television revenue and deals with promotional companies. While dollars spent on athletes has increased, much of the additional dollars have gone to coaches and administrators. This has resulted in the creation of the "haves and the have-nots" in our universities, with the so-called Power 5 conference schools having seemingly unlimited funds while schools in other conferences 
struggle to remain competitive. At many colleges and universities, the general student body may be the real loser, as many schools have adopted student fees or diverted general fund dollars to subsidize their athletic programs. This situation could get worse as coaches' salaries appear to still be rising, conferences are realigning to maximize revenue, and issues concerning the use of an athlete's name, image and likeness will likely change the recruiting landscape. The future of the NCAA seems murky, at best. This overall situation will present challenges for universities in the post-pandemic world.

4. The Shared Governance Model. One thing I have always enjoyed about working at a university is that governance of the university is shared between the administration, faculty, staff, and students. Traditionally, faculty have a large voice in the operation of the university. This is very different from a corporate model where there is little input outside the people who run the corporation. I believe this model may be threatened in the future for several reasons. Increasingly, non-academics with no experience in higher education are being chosen as campus CEOs. Faculty senates, who provide input into the shared governance system are not always representative of the faculty at the university - it is therefore difficult sometimes to ascertain if the input reflects the will of the faculty in general. It is my experience that some faculty don't always have a grip on what is going on in the "real world," perhaps in part due to the relative insulated nature of a college campus. The divide between faculty and legislators and board of trustee members seems to be widening. One can see this in the increasing calls for the elimination of tenure seen over the last few years by people outside of our universities - these individuals simply don't know or understand how a university functions. For shared governance to continue to prevail I believe that administration must become more inclusive in de- cision making, and faculty must become more flexible regarding how universities operate. This became particularly clear during the pandemic.

5. Governing Boards. In nearly all universities and colleges, the ultimate oversight of the institution is in the hands of governing boards, such as Boards of Visitors, Boards of Trustees, or Boards of Regents. Over the course of my time in administration, I have seen a gradual increase in attempts for these boards to manage the day-to-day operation of the university instead of the more global, overarching governance role they should be playing. A good recent example of this overreach was the interference of the system governing board of the University of North Carolina at Chapel Hill in the hiring of renowned journalist Nikole Hannah-Jones to a named chair position (https://www.chronicle.com/article/whatthe-hell-happened). While UNC wanted to hire her as a member of the faculty, her hire was rejected by the governing board for political reasons-she was involved in the development of the 1619 Project of which the political right holds a dim view. Why was the board's action significant? It was a clear demonstration of interference in academic matters, which traditionally have been given to faculty at an institution. Academics depend on peer review, not politics, to determine whether an idea is good, and this should apply to the 1619 Project-historians will determine if the ideas of the project are good or bad. I am not surprised by the rising involvement of boards in the micromanagement of universities. Many boards are political appointees, elected positions, or prominent alumni of the university. Knowledge of how to govern a university is not always the criteria for appointment so it doesn't surprise me that their involvement becomes focused on individual issues about which they are passionate, including politics, athletics, fraternities and sororities, campus parking, and a host of other issues 
that campus CEOs typically don't believe are the most important issues.

6. Research Funding. Research and discovery at our universities essentially ground to a halt during the pandemic as access to laboratories and libraries was difficult. This led to a reduction in research expenditures at most universities. When the pandemic has subsided, there will have to be a period when the investigators attempt to catch up and get their research programs back on track. Graduate students have been significantly affected by the pandemic, as well as their progress toward their degrees, thus delaying their graduation and start of their careers. This delay has affected incoming students; spots in graduate programs normally freed through graduations are occupied. The same can be said for postdoctoral fellows and perhaps new assistant professors as hiring has been delayed somewhat during the pandemic. Some adjustments will have to be made post-pandemic. While research funding has been relatively good over the last decade, I do have concerns about research funding in the future. We must remember that federal funding for research is considered "discretionary" funding. The federal government has spent a lot of money dealing with the pandemic in the recovery acts as well as development of the vaccine. In addition, rather large funds have been approved lately for infrastructure and other needs. Together, these new expenditures have increased the federal deficit significantly. I am concerned that at some point this deficit will be addressed, not through raising taxes but rather through cuts in the discretionary funding. This could put research funding at risk in our post-pandemic world.

7. Succession Planning. As I indicated above, I chose to step down as a campus CEO after the vaccine was made available and as the university began to emerge from the virus. I admire greatly campus CEOs who have continued during this chaotic period. I know a lot of other presidents and chancellors who are contemplating resignations after the pandemic. I predict that there will be a lot of campus CEO vacancies after the pandemic and perhaps not enough individuals with administrative experience to fill the positions. Universities will have to deal with this issue. I, like many other campus CEOs, had a rather traditional academic pathway to the chancellor's position, serving as department chair, dean, and provost prior to taking the campus CEO position. Fewer academics are taking this route these days and that means campus leaders will likely come from other places and have other experiences. The learning curve for these leaders will be steep.

\section{Some Reasons for Optimism}

Much of what I have written here is a rather pessimistic view for the post-pandemic future of our universities. Even though I have decided that I no longer want a role as an administrator at a university, I am very optimistic about the future of our public universities, especially our leading research universities. Here briefly are 10 reasons for optimism:

1. Higher education has faced previous challenges and has effectively addressed them. Universities have changed over the years to meet challenges they faced. Examples are the rapid growth of students after the G.I. Bill was enacted; rapid growth of research and scholarship; anti-tenure movements; campus protests on a variety of topics such civil rights, the Vietnam War, and free speech; and a huge financial crisis in 2009. Universities adjusted and met those challenges, and there is no reason to think that universities will fail to meet challenges created or exacerbated by the pandemic.

2. The pandemic showed that students still want a residential campus experience and are not satisfied in a remote learning world. For years, I have read articles predicting the demise of the brick-and-mortar campus and the increased desire of stu- 
dents for totally online experiences. Feedback I received from students and from my colleagues around the country is that our students missed the experiences they get on a college campus, including social and cultural events, residence hall living, Greek activities, athletics, bonding with other students, and the outside-the-classroom educational experiences in which they seek to participate, such as research and service-learning opportunities. Universities are much more than the classes students attend and for this reason our public universities have a bright futureresidential universities are still relevant.

3. I have often said that the quality of a university is primarily determined by the quality and dedication of the faculty. I do not believe that the pandemic has in any way diminished the enthusiasm or dedication of our faculty to our basic missions of teaching and learning, research and discovery, and outreach and engagement. Across the country our faculty came together in remarkable ways to provide learning opportunities for our students during the pandemic. The core values of our faculty remain strong, and this is good for the future of higher education.

4. In every administrative position I have held, I have stuck to the belief that to improve as a university you should hire faculty who are better than the existing faculty. Indeed, the future of our universities depends on the new faculty we hire. I am very optimistic about the future because the faculty we are hiring at our institutions are outstanding. In my view, they are dedicated to the mission, hungry to succeed, well educated, experienced, flexible, and more collaborative. Above all, our newest faculty, unlike some of their more senior colleagues, seem more willing to try new things and do things in new ways. This will be important in the post-pandemic world as universities strive to meet some of the challenges I outlined above.

5. The need for higher education is as great now as it has ever been if not arguably even greater. Jobs are more complex than ever, and companies are looking for employees with good communication and problem-solving skills and who can think creatively, which should be the result of a good college education. There is a growing need for post-baccalaureate education in the forms of certificates or advanced degrees as employers and employees seek to extend skill sets after an individual has been hired. Universities must step up to offer these educational opportunities before the private sector decides they can assume these responsibilities without the expertise that universities offer. Finally, there are many vexing problems in the world, such as climate change, which can only be addressed through research. Universities provide the country's premier research platform and as such the need for university research has never been greater.

6. I believe that universities are taking social justice and equity issues more seriously than ever before and this is good for all. In the past, attempts have been made to promote a sense of inclusion or belonging within our universities, but the social justice movement energized by reactions to the George Floyd murder and other recent events has instilled a new purpose in universities to address these issues of inequity through education, as well as concrete steps to promote inclusion. I am very hopeful that this issue will remain on the front burner and not simply addressed in the short-term, then shunted aside, which has happened in the past.

7. One thing that has baffled me for years about universities is that members of most university communities either resist change or are slow to change. While some of the brightest individuals in the world work at universities and generally embrace change in their own scholarly disciplines, these same individuals resist change in the operation or organization of the university. I don't know 
how many times I have heard the phrases

"We have never done it that way" or "If it isn't broke, don't fix it," even when there may be better or more efficient ways to do something or to be organized. But the pandemic proved something to me: Universities can be nimble, quick, and flexible as evidenced by the rapid shift to remote learning that was seen and rather quick adjustments that were made after severe changes in operation and the academic environment. I am hopeful that this lesson learned will be extended post-pandemic, and that our universities become known for their ability to be agile and nimble instead of the current perception that universities are places that resist change and are slow to adapt to the "real world" changes around them.

8. Technology continues to advance rapidly, and during the pandemic our universities showed an ability to adopt and use that technology to continue our teaching and research missions. I believe universities will continue to be at the forefront of the development of technology, as well as find creative ways to use new and existing technology to advance the important missions of the university. Universities must figure out how to maximize use of new technology to benefit their missions.

9. There is currently a great need for universities and the private sector to partner for the benefit of both. Businesses are increasingly looking to partner with higher education on teaching and research projects, and I am confident that our re- search universities will participate in these collaborations. This will require give-andtake on both sides as the academic environment and business environment can be quite different. These partnerships may also provide the framework for a new financial model moving forward.

10. Finally, a bit of what I discussed above was based on our current political environment. We recently endured four years of a president's administration that was not friendly to higher education and at times was clearly confrontational. And many of our states currently are governed by individuals with similar thinking. But our history has shown that politics always change as the pendulum swings between right and left. This fact makes me hopeful for the future of higher education. We have survived political shifts before, and we will indeed do so again. I hope we can reach middle ground eventually where compromise is possible.

I close with this: There were several issues facing higher education before the COVID-19 virus took hold around the world, issues that needed to be addressed for universities to thrive. It seems to me that the pandemic exacerbated these issues while creating a few more that need to be addressed over the next several years as the world emerges from the pandemic. But I am quite optimistic that our universities will solve these issues and others that become apparent and will continue to change lives, solve complex problems, and make a significant impact on the world.

\section{Reference}

1. Woods, Randall B. (1995). Fulbright: A Biography. Cambridge Press. 